\title{
NEW CATALYSTS FOR COAL PROCESSING: METAL CARBIDES AND NITRIDES FIRST QUARTERLY REPORT
}

\author{
Grant Number: \\ DE-FG22-95PC95207 \\ RECEIVED \\ Institute: \\ Date of Report: \\ Virginia Polytechnic Institute \& State University JUI 191996 \\ Grant Date: \\ October 30, 1995 \\ July 17, 1995 \\ Anticipated Completion: \\ April 30, 1998 \\ osil \\ Government Award: \\ Contract Manager: \\ Principal Investigators: \\ $\$ 200,000$ \\ Sean Plasynski \\ Contracting Officer's Rep: \\ S. Ted Oyama \& David F. Cox \\ Reporting Period: \\ Udaya Rao \\ July 17, 1995-October 30, 1995
}

\section{DISCLAIMER}

This report was prepared as an account of work sponsored by an agency of the United States Government. Neither the United States Government nor any agency thereof, nor any of their employees, makes any warranty, express or implied, or assumes any legal liability or responsibility for the accuracy, completeness, or usefulness of any information, apparatus, product, or process disclosed, or represents that its use would not infringe privately owned rights. Reference herein to any specific commercial product, process, or service by trade name, trademark, manufacturer, or otherwise does not necessarily constitute or imply its endorsement, recommendation, or favoring by the United States Government or any agency thereof. The views and opinions of authors expressed herein do not necessarily state or reflect those of the United States Government or any agency thereof.

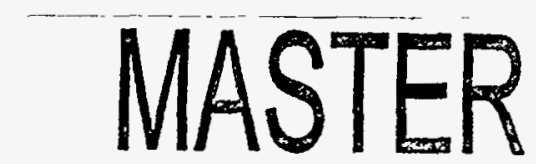




\section{DISCLAMMER}

Portions of this document may be illegible in electronic image products. Images are produced from the best available original document. 


\section{NEW CATALYSTS FOR COAL PROCESSING: METAL CARBIDES AND NITRIDES FIRST QUARTERLY REPORT \\ S. Ted Oyama \& David F. Cox}

\section{Introduction}

Our project deals with the investigation of a new class of catalysts for processing coal liquids. The catalysts are supported carbides and nitrides of transition metals. These compounds are unique because they have properties similar to those of the precious metals, but are resistant to sulfur. Because they have high hydrogenation activity in the presence sulfur, they are ideal for coal processing. For our initial work we have decided to start with unsupported carbides and nitrides in order to identify the best possible composition for our work with supported catalysts. The research includes synthesis, characterization, and testing of the compounds.

\section{Preparation of Unsupported Carbides and Nitrides}

One of our objectives is to understand the synthesis of the materials. In the past most of the work on synthesis has involved molybdenum carbide and nitride and tungsten carbide. Our preliminary work concentrated on an unexplored material: vanadium carbide.

Vanadium carbide (VC) powders were prepared with moderate surface areas of $60 \mathrm{~m}^{2} \mathrm{~g}^{-1}$ (particle size $17 \mathrm{~nm}$ ) by a temperature-programmed reaction (TPR) between solid vanadium pentoxide $\left(19 \mathrm{~m}^{2} \mathrm{~g}^{-1}\right)$ and a methane-hydrogen mixture. The synthesis involved two steps (Fig. 1).

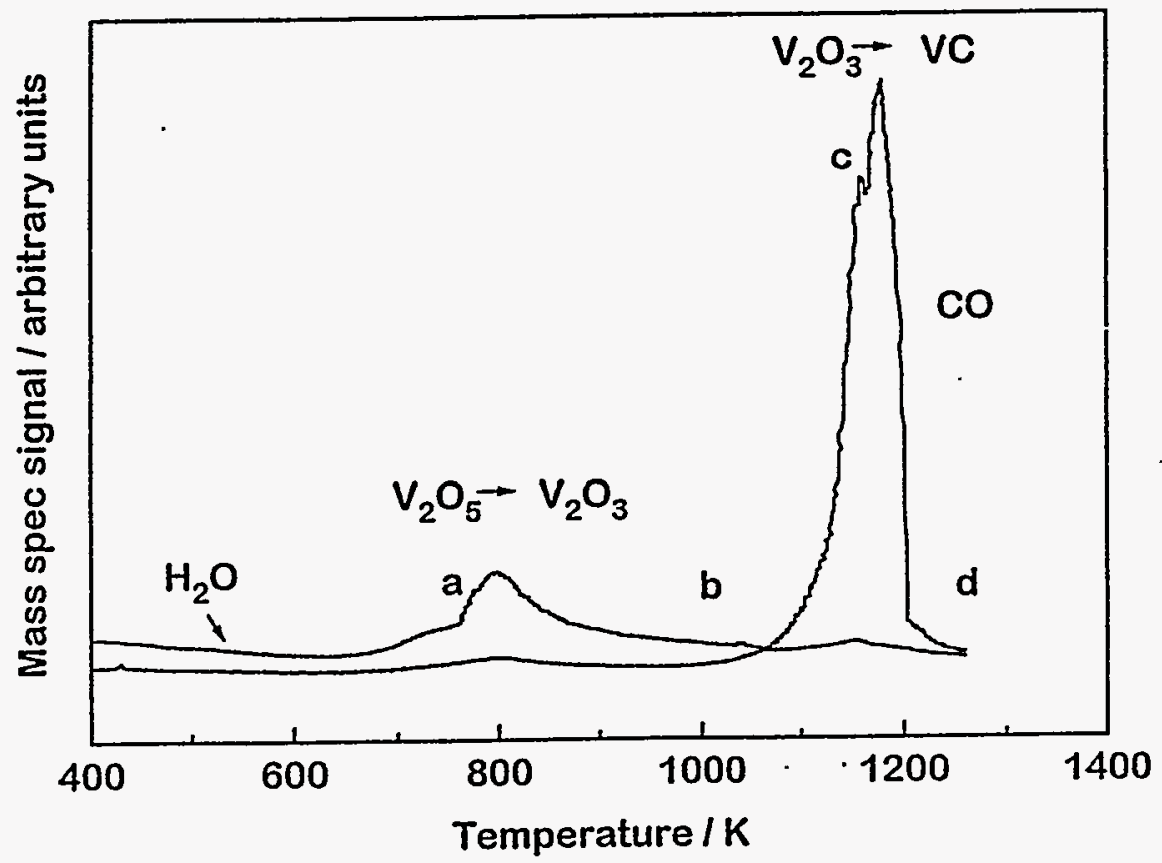

Figure 1.

VC Synthesis by TPR, Mass Spectrometry Signal for $\mathrm{H}_{2} \mathrm{O}$ and $\mathrm{CO}$ vs. Temperature 
In the first step a single suboxide intermediate, $\mathrm{V}_{2} \mathrm{O}_{3}$, was formed by reduction of $\mathrm{V}_{2} \mathrm{O}_{5}$ by hydrogen at $800 \mathrm{~K}$. In the second step the $\mathrm{V}_{2} \mathrm{O}_{3}$ was reduced and carburized by methane with production of $\mathrm{CO}$ at $1180 \mathrm{~K}$. In the early stages the synthesis was found to be limited by the activation of hydrogen, as found by experiments with $\mathrm{Pt} / \mathrm{V}_{2} \mathrm{O}_{5}$. The transformation was accompanied by retention of external shape and size, and so was pseudomorphic, but did not conserve orientation of crystallographic planes, so was not topotactic. The results of this work have been published (Ref. 1 ).

A number of other unsupported compounds were prepared by the TPR method using heating rates and final temperatures available from the literature. The compounds included carbides and nitrides of molybdenum, tungsten, vanadium, niobium, and titanium. The phase purity and composition of the samples were established by X-ray diffraction (XRD) and X-ray photoelectron spectroscopy, while surface properties were determined by $\mathrm{N}_{2} \mathrm{BET}$ and $\mathrm{CO}$ chemisorption measurements. The materials had surface areas ranging from 20 to $80 \mathrm{~m}^{2} \mathrm{~g}^{-1}$. The XRD patterns show that the materials are pure phases (Fig. 2).

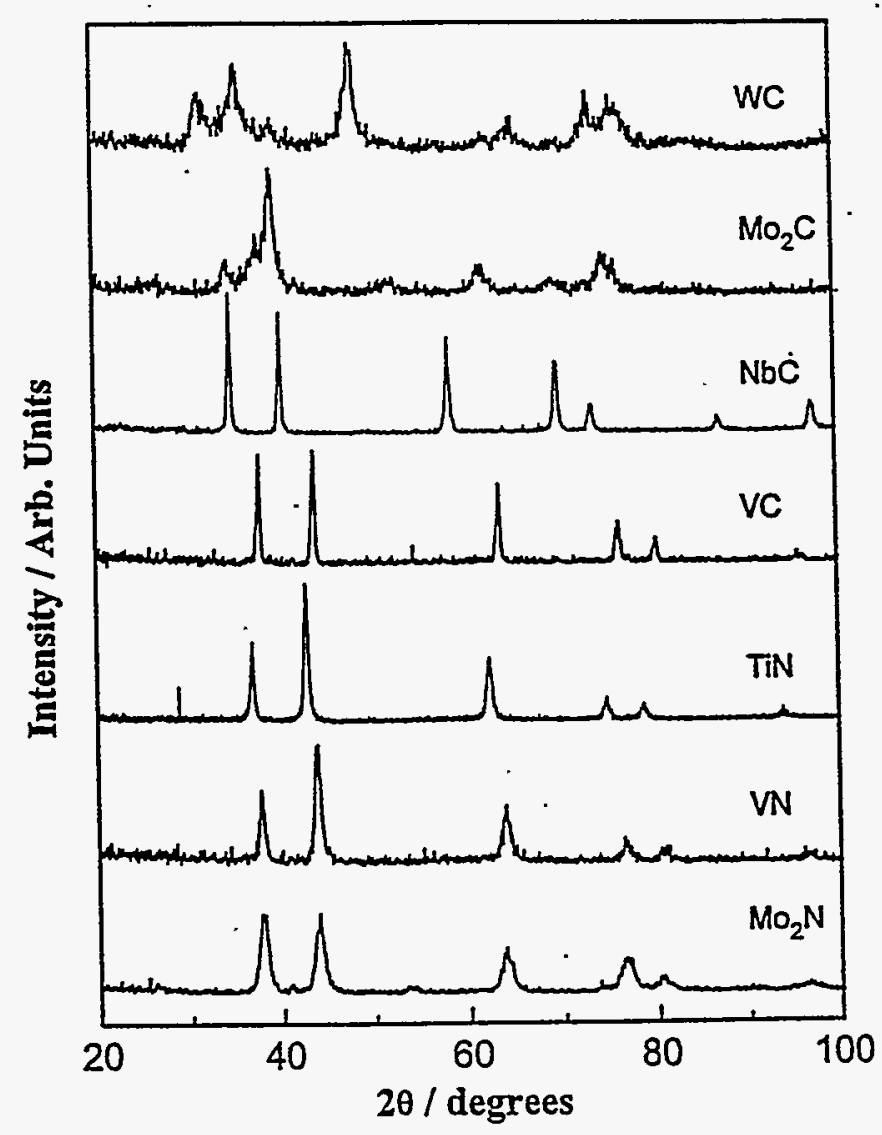

Figure 2.

X-ray Diffraction Patterns of the Fresh Catalysts 


\section{Testing of the Unsupported Catalysts}

The catalysts described above were tested in an existing three-phase trickle-bed reactor for their activity in hydrodenitrogenation (HDN), hydrodesulfurization (HDS), and hydrodeoxygenation (HDO). Particular emphasis was placed on $\mathrm{HDN}$ since it is the most difficult process step due to the strength of C-N bonds in the coal structure. The catalytic tests were carried out using a model liquid feed mixture containing $3000 \mathrm{ppm}$ sulfur (dibenzothiophene), $2000 \mathrm{ppm}$ nitrogen (quinoline), $500 \mathrm{ppm}$ oxygen (benzofuran), $20 \mathrm{wt} \%$ aromatics (tetralin), and balance aliphatics (tetradecane). Tests were conducted at $643 \mathrm{~K}\left(370^{\circ} \mathrm{C}\right)$ and $3.1 \mathrm{MPa}(500$ psig). The order of activity in $\mathrm{HDN}$ and $\mathrm{HDS}$ followed the order $\mathrm{Mo}_{2} \mathrm{C}>\mathrm{WC}>\mathrm{MO}_{2} \mathrm{~N}>\mathrm{NbC}>$ VN $>$ VC $>$ TiN, which corresponded to Group VI $>$ Group V $>$ Group IV (Fig. 3). The comparisons were made on an equal-surface-area-loaded basis. The best compound, $\mathrm{MO}_{2} \mathrm{C}$, was even found to be superior in $\mathrm{HDN}$ to a commercial sulfided $\mathrm{Ni}-\mathrm{Mo} / \mathrm{Al}_{2} \mathrm{O}_{3}$ catalyst. The results have been published (Ref. 2).
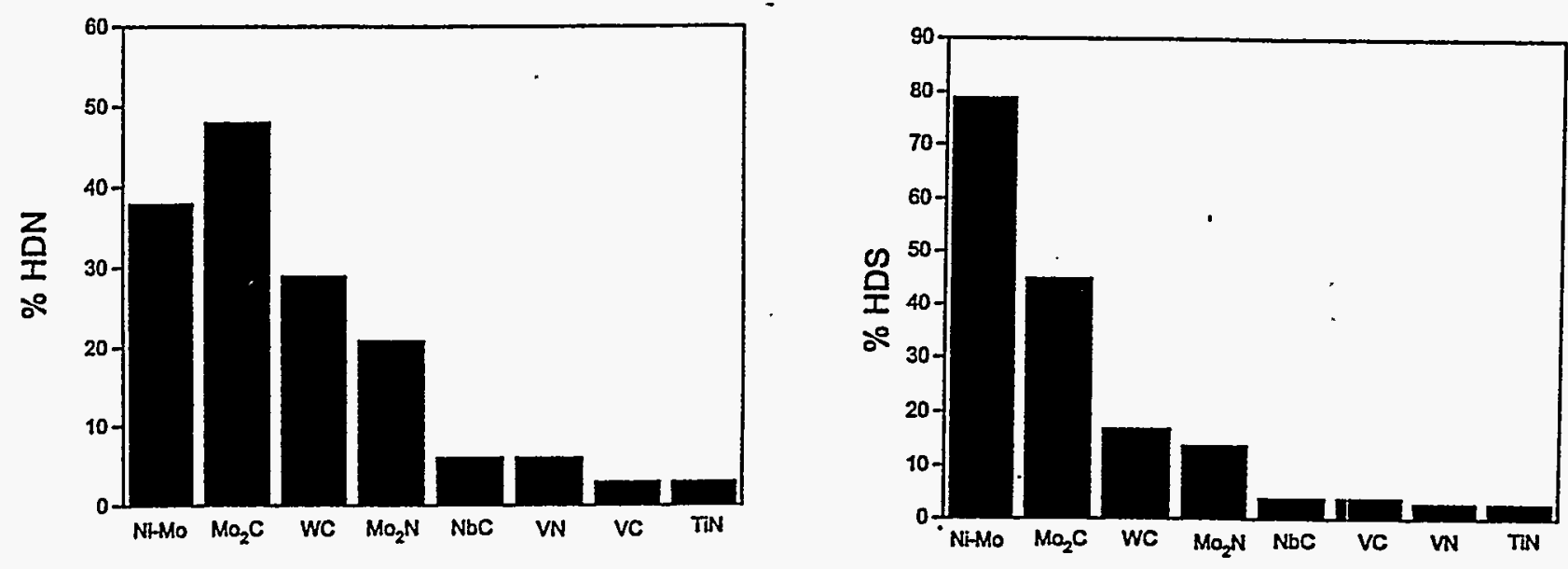

Figure 3

Comparison of HDN (left) and HDS (right) Activities of Compounds with Ni-Mo

\section{Characterization}

Besides routine XRD and surface area measurements it was desired to characterize the transition metal carbides and nitrides spectroscopically to probe their electronic properties. For this reason a collaboration was made with a group from the Exxon company (Frühberger, DeVries and Chen) to measure near-edge X-ray absorption fine structure (NEXAFS) spectra. The following compounds were investigated: $\mathrm{TiC}, \mathrm{VC}, \mathrm{NbC}, \mathrm{MO}_{2} \mathrm{C}, \mathrm{WC}, \mathrm{TiN}, \mathrm{VN}$, and $\mathrm{MO}_{2} \mathrm{~N}$. The NEXAFS spectra of the carbides are reported in Fig. 4. The spectra reveal substantial 
alteration of the electronic state of the compounds compared to the pure metals, and some charge donation from the metal to the nonmetal. This is consistent with the noble-metal like reactivity of the compounds. The results have been published (Ref. 3).

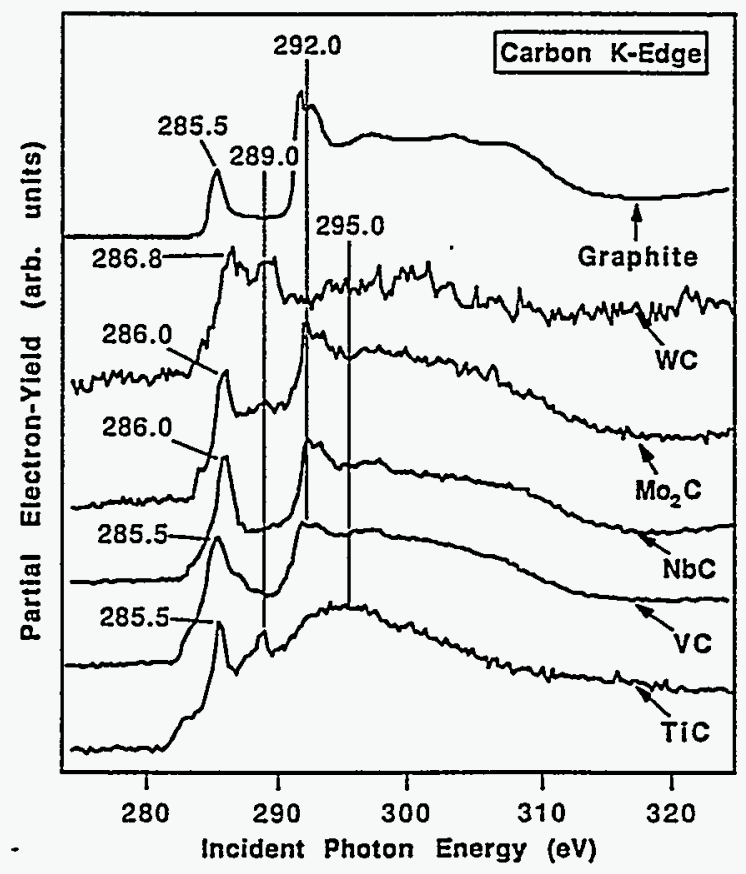

Figure 4

\section{The NEXAFS of Carbon K-edge Features of Carbide Samples}

\section{Future Work}

In the next period we will explore the reactivity of the carbides and nitrides in another environmentally important reaction, dechlorination of freons. This is because of the high hydrogenation activity displayed in these early measurements. We will then turn our attention on the synthesis of some novel compounds: bimetallic alloys of the nitrides.

\section{References}

1. Synthesis of Vanadium Carbide by Temperature Programmed Reaction

R. Kapoor and S. T. Oyama

J. Solid State Chem. 1995, 120, 320.

2. New Catalysts for Hydroprocessing: Transition Metal Carbides and Nitrides

S. Ramanathan and S. T. Oyama

J. Phys. Chem. 1995, 99, 16365.

3. Characterization of Early Transition Metal Carbides and Nitrides by NEXAFS

R. Kapoor, S. T. Oyama, B. Frühberger, B. D. DeVries and J. G. Chen

Catal. Lett. 1995, 34, 179. 